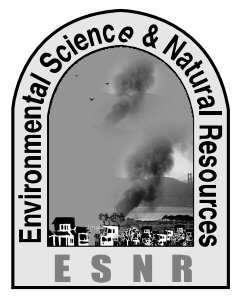

J. Environ. Sci. \& Natural Resources, 5(1): 179 - 185, 2012

ISSN 1999-7361

\title{
Influence of Soil Amendments on Mitigating Methane Emissions and Sustaining Rice Productivity in Paddy Soil Ecosystems of Bangladesh
}

\author{
M. A. Ali ${ }^{1}$, M. G. Farouque ${ }^{2}$, M. Haque ${ }^{3}$ and Abid ul Kabir ${ }^{4}$ \\ ${ }^{1,4}$ Department of Environmental Science, BAU, Mymensingh \\ ${ }^{2}$ Department of Agricultural Extension Education, BAU, Mymensingh \\ ${ }^{3}$ Graduate Training Institute, BAU, Mymensingh
}

\begin{abstract}
Two field experiments were conducted at two different rice ecosystems, one in the upland rice field of Bangladesh Agricultural University farm, Mymensingh and the another one in the low lying area of Bhaluka, Mymensingh to investigate the effects of soil amendments on mitigation of methane emissions and sustaining rice productivity. The experimental treatments were urea $(250 \mathrm{~kg}$ $\left.\mathrm{ha}^{-1}\right)$, urea plus coal ash $\left(1 \mathrm{t} \mathrm{ha}^{-1}\right)$, urea plus phosphogypsum $\left(90 \mathrm{~kg} \mathrm{ha}^{-1}\right)$, urea plus silicate fertilizer $\left(150 \mathrm{~kg} \mathrm{ha}^{-1}\right)$, ammonium sulphate $400 \mathrm{~kg} \mathrm{ha}^{-1}$, ammonium sulphate plus silicate fertilizer $\left(150 \mathrm{~kg} \mathrm{ha}^{-1}\right)$, urea $(25 \%$ less than the recommended doze $)$ plus cyanobacteria plus azolla $\left(1 \mathrm{t} \mathrm{ha}{ }^{-1}\right.$ ). In case of BAU upland rice field, the total seasonal $\mathrm{CH}_{4}$ emission was decreased by $12-21 \%$ and rice grain yield was increased by 4.0-18.0\% respectively, whereas 11.0-26.0\% reduction in total $\mathrm{CH}_{4} \mathrm{emission}^{2}$ and $4.5-24.0 \%$ increase in rice grain yield was recorded from the low lying rice field of Bhaluka with the application of soil amendments. Among the amendments silicate fertilization with urea and silicate in combination with ammonium sulphate reduced total $\mathrm{CH}_{4}$ flux by 18 $23 \%$ and $21-26 \%$ respectively, whereas rice grain yield was increased by $18-24 \%$ and $16-18 \%$, respectively in both ecosystems. Although maximum reduction in total seasonal $\mathrm{CH}_{4}$ flux was recorded with silicate and sulfate of ammonia amendment in paddy soil, however soil acidity was developed which might affect soil fertility and rice productivity in the future. Therefore, silicate fertilizer could be introduced with the nitrogenous fertilizer sources, preferably with $50 \%$ urea plus $50 \%$ ammonium sulphate for reducing $\mathrm{CH}_{4}$ emissions and increasing rice productivity under both irrigated upland and lowland rice field ecosystems.
\end{abstract}

Kew words: Methane emission, Rice, Soil amendment

\section{Introduction}

Rice is the main food crop in Bangladesh. Rain fed (Tropical Monsoon) lowland and irrigated rice farming mainly dominates rice productivity that contributes significant amount of $\mathrm{CH}_{4}$ emissions to the atmosphere. The impacts of climate change on agricultural food production are global concerns and crucial for the economy of Bangladesh, as 35\% of country's GDP comes from agriculture sector. $\mathrm{CH}_{4}$ emission from the lowland and irrigated rice field is a major environmental problem, which causes global warming due to its radiative effects (IPCC 2001). Bangladesh is a low-lying deltaic country in South Asia. Rice cropping intensity is very high, e.g., three times in a year, which may degrade the environment due to continuous emissions of greenhouse gases, e.g., $\mathrm{CH}_{4}$ gas from rice field. Total rice production in Bangladesh was 34.28 million tons in FY2008-09 (BBS, 2009), where Boro rice contributed 57\% (18.5 million tons), T. Aman rice $33 \%$ and Aus rice $10 \%$. Bangladesh will require more than 55.0 million tons of rice to meet the food demand of the expected total population (233.0 millions) by the year 2050 (Basak, 2009). Therefore, the area under rice cultivation especially boro rice field must be expanded, which may cause significant $\mathrm{CH}_{4}$ emissions and eventually may accelerate the global warming effects. Silicate slag, which is a byproduct of steel industry, is used in manufacturing of silicate fertilizer that contains high amount of available silicate, active iron, free iron and manganese oxides, may act as electron acceptors. Ali et al. (2009) reported that $\mathrm{CH}_{4}$ flux was significantly decreased during rice cultivation by silicate amendment in paddy soils. Phospho-gypsum, a byproduct of phosphate fertilizer manufacturing industry, is another feasible soil amendment to supplement mainly calcium and sulfur for rice cultivation. The high content of sulfate in phosphogypsum might prevent $\mathrm{CH}_{4}$ formation as well as $\mathrm{CH}_{4}$ emissions due to stronger competitor for substrates (hydrogen or acetate) than methanogens (Hori et al., 1990, 1993;. Cyanobacteria are important biotic components of the wetland paddy ecosystem, commonly found as floating assemblages (a water fern harbouring a cyanobacterium, Anabaena azollae) in rice paddies. It has already reported that cyanobacterial mixture plus Azolla microphylla applied to flood water rice field, enhanced $\mathrm{CH}_{4}$ oxidation and eventually decreased $\mathrm{CH}_{4}$ emission (Bharati et al, 2000; Prasanna et al., 2002).

In the present context of Bangladesh, no basic information on reducing $\mathrm{CH}_{4}$ emissions from rice field are available. Our rice farmers must upgrade and well equip themselves with the scientific principles of rice paddy ecosystems management. So, the present research work was undertaken to investigate the 
influence of soil amendments on $\mathrm{CH}_{4}$ emission and rice productivity in lowland and upland paddy soil ecosystems.

\section{Materials and Methods}

\section{Experimental field preparation and rice cultivation}

Two field experiments were conducted at two different rice ecosystems, one in the upland rice field of Bangladesh Agricultural University farm, Mymensingh and the another one in the low lying area of Bhaluka, Mymensingh. The experiments were designed with randomized complete block design (RCBD). There were seven treatments, which were replicated three times in each experimental field. The experimental treatments were urea $250 \mathrm{~kg}$ $\mathrm{ha}^{-1}$, urea $250 \mathrm{~kg} \mathrm{ha}^{-1}+$ coal ash $1 \mathrm{t} / \mathrm{ha}$, urea $250 \mathrm{~kg} \mathrm{ha}^{-}$ ${ }^{1}+$ phospho- gypsum $90 \mathrm{~kg} \mathrm{ha}^{-1}$, urea $250 \mathrm{~kg} \mathrm{ha}^{-1}+$ silicate fertilizer $150 \mathrm{~kg} \mathrm{ha}^{-1}$, sulphate of ammonia (SOA) $400 \mathrm{~kg} \mathrm{ha}^{-1}$, sulphate of ammonia (SOA) 400 $\mathrm{kg} \mathrm{ha}^{-1}+$ silicate fertilizer $150 \mathrm{~kg} \mathrm{ha}^{-1}$, urea $(190$ $\mathrm{kg} / \mathrm{ha}, 25 \%$ less than the recommended doze) + cyanobacterial bloom (cyanobacteria + azolla) 1 ton/ha, sulphate of ammonia (SOA) $400 \mathrm{~kg} \mathrm{ha}^{-1}+$ cyanobacterial bloom (cyanobacteria + azolla) 1 ton/ha. The rice cultivar used in this experiment was BRRI Dhan-29. The selected silicate fertilizer was granular form, slag type with $\mathrm{pH} 9.5$ and was composed mainly of $\mathrm{CaO}(41.8 \%), \mathrm{SiO}_{2}(33.5 \%)$ and $\mathrm{Fe}_{2} \mathrm{O}_{3}$ (5.4\%). Average active and free iron concentrations were 3078 and $1571 \mathrm{mg} \mathrm{Fe} \mathrm{kg}^{-1}$, respectively. The basal nutrients fertilizer applied following the ratio $\mathrm{N}: \mathrm{P}_{2} \mathrm{O}_{5}: \mathrm{K}_{2} \mathrm{O}=110: 45: 60 \mathrm{~kg}$ ha

${ }^{1}$. Dried rice straw was added into soils at the rate of 2 $\mathrm{t}$ ha ${ }^{-1}$ one week prior to flooding and mixed mechanically within $10 \mathrm{~cm}$ depth of the surface soil. The content of electron acceptors were $1.2 \%, 3.5 \%$, $5.7 \%, 5.9 \%, 4.0 \%$ and $6.3 \%$ in urea, urea plus coal ash, urea plus silicate slag, urea plus phosphogypsum, sulfate of ammonia, and silicate slag plus sulfate of ammonia, respectively. The selected soil amendments having electron acceptors were applied in the selected rice field two days before final land preparation (Ali et al, 2009). Cyanobacterial mixture plus azolla was inoculated in field plots at $1 \mathrm{Mg} \mathrm{ha}^{-1}$ after one week of rice transplanting and allowed to grow with rice plant as dual crop. Twenty eight days old rice seedlings of cultivar BRRI Dhan-29 were transplanted in the field $25 \mathrm{~cm} \times 25 \mathrm{~cm}$ with single plant hill ${ }^{-1}$.

\section{$\mathrm{CH}_{4}$ gas sampling and analysis}

Gas sampling was carried out through closedchamber method (Rolston, 1986) during rice cultivation. Three glass chambers were placed in each plot. Four holes at the bottom of each chamber were kept to facilitate water movement. The air gas samples from the transparent glass chamber (Diameter $62 \mathrm{~cm}$, and height $112 \mathrm{~cm}$ ) were collected by using $50 \mathrm{ml}$ gas-tight syringes at 0,15 and 30 minutes intervals after chamber placement over the rice planted plots. Gas samples were collected three times (8.00-12.00-16.00) in a day to get the average $\mathrm{CH}_{4}$ emissions during the cropping season. $\mathrm{CH}_{4}$ concentrations in the collected air samples were measured by Gas Chromatography (Shimadzu, GC2010) packed with Porapak NQ column (Q 80-100 mesh) and a flame ionization detector (FID). The temperatures of column, injector and detector were adjusted at $100^{\circ} \mathrm{C}, 200^{\circ} \mathrm{C}$, and $200^{\circ} \mathrm{C}$ respectively. Helium $(\mathrm{He})$ and $\mathrm{H}_{2}$ gases were used as carrier and burning gases, respectively.

\section{Estimation of $\mathrm{CH}_{4}$ Flux}

$\mathrm{CH}_{4}$ emission from irrigated rice field was calculated from the increase in $\mathrm{CH} 4$ concentrations per unit surface area of the chamber for a specific time intervals. A closed chamber equation (Rolston, 1986) was used to estimate $\mathrm{CH}_{4}$ fluxes from each treatment.

$\mathrm{F}=\rho . \mathrm{V} / \mathrm{A} . \Delta \mathrm{c} / \Delta \mathrm{t} \cdot 273 / \mathrm{T}$

where, $\mathrm{F}=$ methane flux $\left(\mathrm{mg} \mathrm{CH}_{4} \mathrm{~m}^{2} \mathrm{hr}^{-1}\right), \rho=$ gas density $\left(0.714 \mathrm{mg} \mathrm{cm}^{-3}\right)$,

$\mathrm{V}=$ volume of chamber $\left(\mathrm{m}^{3}\right), \mathrm{A}=$ surface area of chamber $\left(\mathrm{m}^{2}\right)$,

$\mathrm{H}=$ height of the chamber $(\mathrm{m}), \Delta \mathrm{c} / \Delta \mathrm{t}=$ rate of increase of methane gas concentration in the

Chamber $\left(\mathrm{mg} \mathrm{m}^{-3} \mathrm{hr}^{-1}\right)$,

$\mathrm{T}$ (absolute temperature $)=273+$ mean temperature in chamber $\left({ }^{\circ} \mathrm{C}\right)$.

\section{Investigation of soil chemical properties}

Soil redox potential (Eh) and water $\mathrm{pH}$ were measured every week interval by Eh meter (PRN-41, DKK-TOA Corporation) and $\mathrm{pH}$ meter (Orion 3 star, Thermo electron corporation), respectively, during rice cultivation. Changes in the organic matter content and dissolved organic carbon (Wakley and Black method; Allison 1965), available silicate (1 M Na-acetate $\mathrm{pH} 4.0$, UV spectrometer) and available phosphate (Lancaster method, RDA 1988), water soluble and ferrous iron (Water extraction , 2M Naacetate solution; 1,10 Phenanthroline method), exchangeable $\mathrm{Ca}^{2+}, \mathrm{Mg}^{2+}$, and $\mathrm{K}^{+}\left(1 \mathrm{M} \mathrm{NH}_{4}\right.$-acetate pH 7.0, AA, Shimazu 660), nitrate and ammonium ion concentrations were determined through standard analytical methods. Ferrous iron concentrations in 
fresh soil samples were determined by $2 \mathrm{M}$ Na-acetate extraction method (Modified from Kumada and Asami, 1958). The total iron, active iron and free iron concentrations in the dried soil at harvesting time were determined by modified acid $(12 \mathrm{M} \mathrm{HCl})$ digestion, acid ammonium oxalate in darkness and citrate dithionite bicarbonate dissolution procedures, respectively (Loeppert and Inskeep, 1996).

\section{Investigation of rice plant growth and yield characteristics}

Rice growth and yield components were recorded under different treatments and locations. Yield components such as panicle number per hill, number of grains per panicle, ripened grains, 1000 grain weight, harvest index and grain yield/ha were determined at the harvesting stage.

\section{Statistical analysis}

Statistical analyses were conducted using SAS software (Anonymous, 1990). Rice growth, yield, soil properties and methane emission data were subjected to the analysis of variance and regression. Fisher's protected least significant difference (LSD) was calculated at the 0.05 probability level for making treatment mean comparisons.

\section{Results and Discussion}

$\mathrm{CH}_{4}$ flux measured at 21 days after rice transplanting was low, which increased significantly with plant growth and the development of soil reductive condition in both upland rice field of BAU and lowland rice field of Bhaluka, respectively. The highest $\mathrm{CH}_{4}$ peak was observed at flowering to heading stage (77-91 days after rice transplanting) in both locations of BAU and Bhaluka rice fields, respectively (Fig.1). However, $\mathrm{CH}_{4}$ emission rate was comparatively higher from the lowland rice field than that of upland rice field during rice cultivation period.

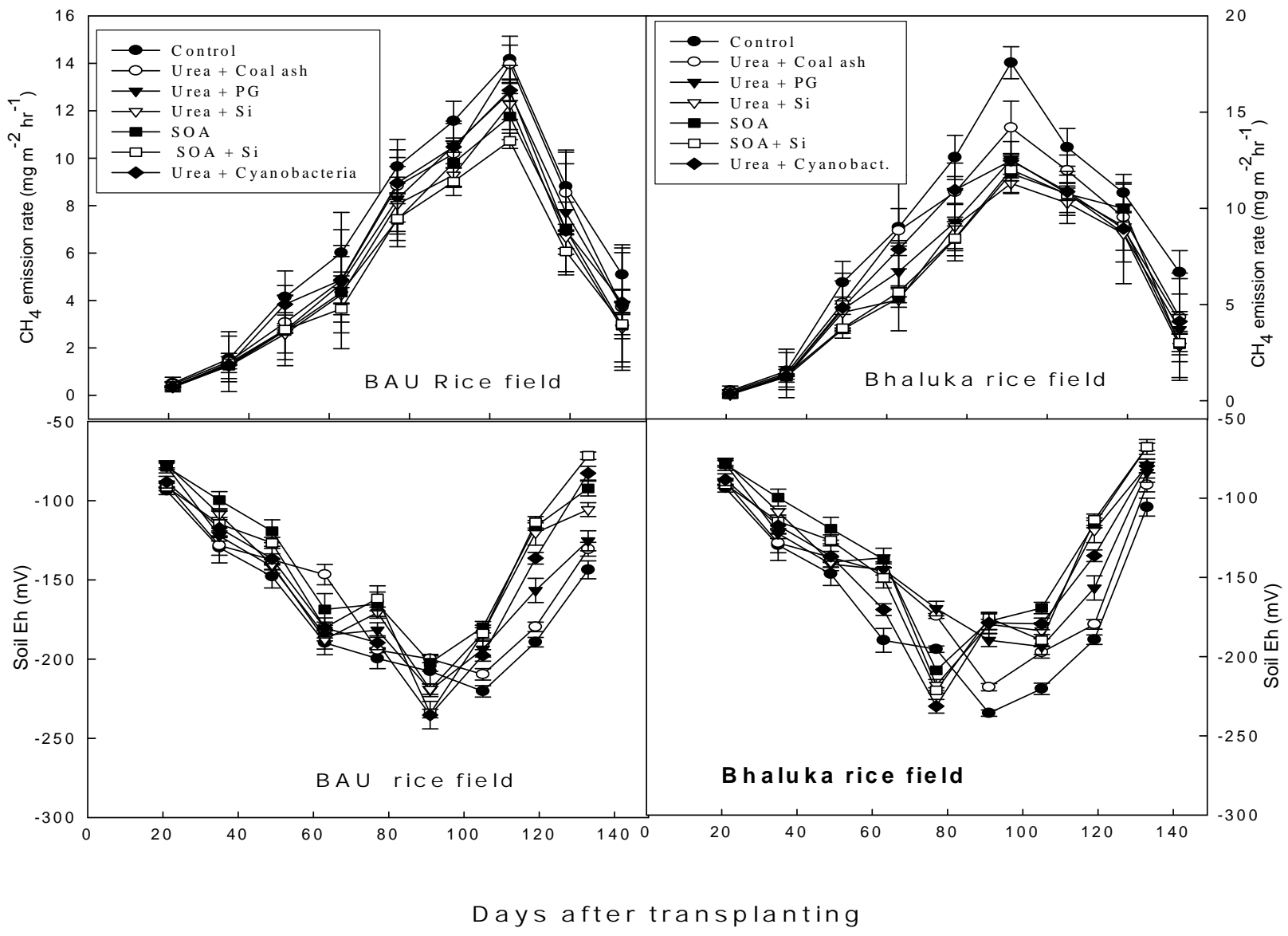

Fig. 1. Trends of $\mathrm{CH}_{4}$ emission rate and soil Eh during rice cultivation at BAU and Bhaluka rice field 
This was probably due to the development of intense reduced conditions, e.g., redox potential value (soil Eh) $-220 \mathrm{mV}$ to $-240 \mathrm{mV}$ in the rice rhizosphere (Fig.1) and the availability of soil organic carbon. Soil amendments such as silicate fertilization with urea and ammonium sulfate, phospho- gypsum amendment with urea significantly decreased $\left({ }^{*} \mathrm{p}<0.05\right) \quad \mathrm{CH}_{4}$ emission rate as compared to other treatments during rice cultivation (Fig.1). At ripening stage, $\mathrm{CH}_{4}$ emission rates decreased sharply in both locations (Fig 1), which seems to be related with plant aging and improved soil porosity, being supported by Aulakh et al. (2000).

Silicate fertilization with urea and silicate plus ammonium sulphate amendments significantly stimulated the growth and yield components of rice, thereby significantly increased the grain yield as compared to other treatments (Table 1). Among the treatments, silicate amendment with urea increased maximum rice grain yield from the control plot 4189 to $4963 \mathrm{~kg} \mathrm{ha}^{-1}$ (18\% yield increased), 4450 to 5520 $\mathrm{kg} \mathrm{ha}^{-1}$ (24\% yield increased) in BAU and Bhaluka rice field, respectively (Table 1). The seasonal total $\mathrm{CH}_{4}$ flux from the upland BAU rice field was 105.5 $\mathrm{kg} \mathrm{ha}{ }^{-1}$ under the control treatment, which was decreased by $11.8 \%, 14.7 \%, 18 \%, 15 \%, 20.8 \%$ and
$13.5 \%$ with urea plus coal ash, urea plus phosphogypsum, urea plus silicate fertilizer, ammonium sulphate, ammonium sulphate plus silicate fertilizer, and cyanobacterial bloom with urea amendments respectively; whereas rice grain yield was increased by $6 \%, 11 \%, 18 \%, 5 \%, 16 \%$ and $7 \%$ respectively, (Table 1). In case of lowland rice field of Bhaluka the seasonal total $\mathrm{CH}_{4}$ flux was $129.0 \mathrm{~kg} \mathrm{CH} \mathrm{Cha}^{-1}$ under the control treatment, which was decreased by $13 \%, 18 \%, 23 \%, 21 \%, 26 \%$, and $11 \%$ with urea plus coal ash, urea plus phosphogypsum, urea plus silicate fertilizer, SOA, SOA and silicate fertilizer and cyanobacterial bloom with urea amendments, respectively whereas rice grain yield was increased by $7 \%, 12.8 \%, 24 \%, 4.5 \%, 18 \%$ and $8 \%$, respectively (Table 1).

Among the treatments urea plus silicate fertilizer and ammonium sulfate plus silicate fertilizer significantly reduced total methane flux and increased rice grain yield. Although phospho-gypsum and ammonium sulfate amendments effectively reduced $\mathrm{CH}_{4}$ emissions, however developed soil acidity, therefore, silicate fertilization with urea could be the best amendment for mitigating $\mathrm{CH}_{4}$ emissions and increasing rice productivity.

Table 1. Rice yield components, grain yield, and total $\mathrm{CH}_{4}$ flux of paddy soil ecosystems at harvest

\begin{tabular}{|c|c|c|c|c|c|c|c|}
\hline $\begin{array}{l}\text { Locations } \\
\text { (A) }\end{array}$ & $\begin{array}{l}\text { Soil amendments } \\
\text { (B) }\end{array}$ & $\begin{array}{c}\text { No. of panicles } \\
\mathbf{m}^{-2}\end{array}$ & $\begin{array}{l}\text { No. of } \\
\text { grains/ } \\
\text { panicle }\end{array}$ & $\begin{array}{l}\text { Ripening } \\
\text { ratio }\end{array}$ & $\begin{array}{c}\text { Grain Yield } \\
\left(\mathrm{kg} \mathrm{ha}^{-1}\right)\end{array}$ & $\begin{array}{c}\text { Straw } \\
\text { Yield } \\
\left(\mathrm{kg} \mathrm{ha}^{-1}\right)\end{array}$ & $\begin{array}{c}\text { Seasonal } \mathrm{CH}_{4} \\
\text { flux } \\
\left(\mathrm{kg} \mathrm{CH}_{4} \mathrm{ha}^{-1}\right) \\
\end{array}$ \\
\hline \multirow{7}{*}{$\begin{array}{l}\text { BAU Site } \\
\text { (Upland) }\end{array}$} & Urea alone & 345 & 119 & 84.5 & 4189 & 4050 & 105.5 \\
\hline & Urea + coal ash & 378 & 127 & 88.9 & 4457 & 4125 & 93.0 \\
\hline & Urea + phosphogypsum & 423 & 138 & 89.5 & 4676 & 4370 & 90.0 \\
\hline & Urea + silicate slag & 441 & 149 & 93.5 & 4963 & 4560 & 86.5 \\
\hline & Ammonium sulphate & 399 & 123 & 87.5 & 4276 & 4045 & 89.0 \\
\hline & $\begin{array}{l}\text { Ammonium sulphate + } \\
\text { silicate slag }\end{array}$ & 433 & 135 & 92.5 & 4875 & 4390 & 83.5 \\
\hline & $\begin{array}{l}\text { Urea + Cyanobacteria + } \\
\text { azolla }\end{array}$ & 420 & 127 & 90.5 & 4493 & 4125 & 91.3 \\
\hline \multirow{7}{*}{$\begin{array}{l}\text { Bhaluka Site } \\
\text { (Lowland) }\end{array}$} & Urea alone & 357 & 123 & 86.6 & 4450 & 4125 & 129.0 \\
\hline & Urea + coal ash & 399 & 133 & 90.5 & 4780 & 4250 & 112.0 \\
\hline & Urea + phosphogypsum & 427 & 148 & 91.3 & 5021 & 4325 & 105.0 \\
\hline & Urea + silicate slag & 462 & 155 & 92.5 & 5520 & 4550 & 98.6 \\
\hline & Ammonium sulphate & 420 & 135 & 89.9 & 4650 & 4310 & 102.0 \\
\hline & $\begin{array}{l}\text { Ammonium sulphate + } \\
\text { silicate slag }\end{array}$ & 441 & 151 & 93.1 & 5245 & 4770 & 95.5 \\
\hline & $\begin{array}{l}\text { Urea + cyanobacteria + } \\
\text { azolla }\end{array}$ & 433 & 139 & 91.5 & 4820 & 4650 & 114.5 \\
\hline \multirow{3}{*}{ ANOVA } & $\mathrm{A}$ & $* * *$ & $* *$ & $* *$ & $* * *$ & $*$ & $* * *$ \\
\hline & $\mathrm{B}$ & $* * *$ & $* *$ & ** & **** & $*$ & **** \\
\hline & $\mathrm{A} \times \mathrm{B}$ & * & * & * & $*$ & ns & $*$ \\
\hline
\end{tabular}

Notes: $* * *$ and $* * *$ means significant at $5 \%, 1 \%$ and $0.1 \%$, levels, respectively; ns means not significant. 
Silicate fertilizer, phospho-gypsum and sulfate of ammonia amendments significantly $(p<0.05)$ increased soil porosity and improved soil redox potential (Eh) status as compared to that of control (Table 2), which could be due to their higher content active iron oxide, ferric and sulfate ions in the amended paddy soil, which acted as oxidizing agents as well as electron acceptors (Table 2). The soil $\mathrm{pH}$ significantly $(\mathrm{P}<0.001)$ increased with silicate fertilization, probably due to release of base cations such as $\mathrm{Ca}^{2+}$ from the applied amendment. Similar trends of changes in soil Eh and flood water $\mathrm{pH}$ were reported by Ali et al. (2008). The available $\mathrm{P}_{2} \mathrm{O}_{5}$ and $\mathrm{SiO}_{2}$, exchangeable cations such as $\mathrm{Ca}, \mathrm{Mg}$ and $\mathrm{K}$ etc., and the concentrations of active iron, free iron and ferrous iron oxides in soil significantly $(\mathrm{P}<0.001)$ increased under the silicate and phospho-gypsum amendments with urea and ammonium sulfate (Table 2). This implies that the silicate and phospho-gypsum amendments supplied large amount of ferric oxides and sulfate ions which acted as oxidizing agents and electron acceptors, thereby suppressed $\mathrm{CH}_{4}$ production rates from the anoxic paddy soils, being supported by Watanabe and Kimura (1999); Jackel and Schnell (2000). The interaction of soil amendments with the ecosystems significantly improved the soil physicochemical properties, which ultimately decreased total seasonalCH $\mathrm{C}_{4}$ emissions and increased rice grain yield.

Table 2. Chemical properties of rice paddy soils at rice harvesting stage

\begin{tabular}{|c|c|c|c|c|c|c|c|c|c|c|c|c|c|c|c|}
\hline \multirow{4}{*}{ Soil Properties } & \multicolumn{7}{|c|}{ BAU rice field } & \multicolumn{7}{|c|}{ Bhaluka rice field } & \multirow{4}{*}{$\begin{array}{l}\text { LSD } \\
0.05\end{array}$} \\
\hline & Ure & Ure & Ure & Urea & SO & SOA & Ure & Ure & Ure & Urea & Urea & SO & SOA & Ure & \\
\hline & sole & Coa & + & Silicate & & Silicate & + & sole & Coa & PG & & & silicate & + & \\
\hline & & 1 ash & PG & & & & $\mathrm{CB}$ & & lash & \multicolumn{3}{|c|}{ silicate } & & $\mathrm{CB}$ & \\
\hline Soil porosity & 0.51 & 0.52 & 0.54 & 0.56 & 0.52 & 0.55 & 0.54 & 0.50 & 0.51 & 0.52 & 0.54 & 0.52 & 0.54 & 0.53 & 0.01 \\
\hline Soil pH & 6.6 & 6.8 & 6.7 & 7.0 & 6.7 & 6.8 & 6.8 & 6.7 & 6.9 & 6.8 & 7.2 & 6.6 & 6.9 & 6.9 & 0.03 \\
\hline Soil Eh & -89 & -78 & -65 & -63 & -60 & -57 & -71 & -93 & -80 & -63 & -67 & -58 & -55 & -75 & 4.9 \\
\hline $\mathrm{OM}\left(\mathrm{g} \mathrm{kg}^{-1}\right)$ & 24.9 & 25.5 & 26.0 & 26.9 & 25.1 & 27.5 & 27.0 & 25.3 & 25.7 & 26.0 & 26.9 & 26.1 & 27.5 & 28.1 & 2.94 \\
\hline $\begin{array}{l}\text { Available } \mathrm{P}_{2} \mathrm{O}_{5} \\
\left(\mathrm{mg} \mathrm{kg}^{-1}\right)\end{array}$ & 58.5 & 69.5 & 87.5 & 109.0 & 93 & 115.0 & 109 & 61.5 & 70.5 & 89.5 & 118 & 97.0 & 129.0 & 112 & 12.0 \\
\hline $\begin{array}{l}\text { Available } \mathrm{SiO}_{2} \\
\left(\mathrm{mg} \mathrm{kg}^{-1}\right)\end{array}$ & 65.0 & 89.5 & 107 & 131.0 & 103 & 129 & 110 & 61.5 & 98.0 & 91.0 & 139.5 & 99.0 & 115.0 & 121 & 2.70 \\
\hline $\operatorname{Ex} . \mathrm{Ca}\left(\mathrm{cmol}^{+} \mathrm{kg}^{-1}\right)$ & 3.9 & 4.5 & 6.9 & 5.6 & 4.3 & 6.3 & 5.1 & 3.6 & 4.3 & 5.1 & 6.1 & 6.3 & 5.1 & 5.3 & 0.35 \\
\hline Ex.Mg $\left(\mathrm{cmol}^{+} \mathrm{kg}^{-1}\right)$ & 1.2 & 1.5 & 1.6 & 1.6 & 1.3 & 1.5 & 1.5 & 1.1 & 1.2 & 1.4 & 1.5 & 1.30 & 1.4 & 1.6 & 0.11 \\
\hline Ex.K $\left(\mathrm{cmol}^{+} \mathrm{kg}^{-1}\right)$ & 0.24 & 0.31 & 0.35 & 0.39 & 0.33 & 0.36 & 0.35 & 0.27 & 0.34 & 0.41 & 0.45 & 0.43 & 0.47 & 0.39 & 0.03 \\
\hline $\begin{array}{l}\text { Active iron } \\
\left(\mathrm{g} \mathrm{Fe} \mathrm{kg}^{-1}\right)^{\mathrm{a}}\end{array}$ & 10.8 & 10.9 & 11.5 & 13.5 & 10.9 & 12.5 & 10.9 & 10.7 & 11.3 & 12.5 & 14.9 & 12.9 & 14.9 & 11.0 & 0.36 \\
\hline $\begin{array}{l}\text { Ferrous iron } \\
\left(\mathrm{mg} \mathrm{Fe}^{2+} \mathrm{kg}^{-1}\right)^{\mathrm{b}}\end{array}$ & 89.3 & 129 & 147 & 179 & 187 & 195 & 149 & 97.5 & 148 & 187 & 191 & 183 & 193 & 135 & 19.4 \\
\hline $\begin{array}{l}\text { Water soluble } \mathrm{SO}_{4}^{2-} \\
(\mathrm{mg} \mathrm{kg}-1)\end{array}$ & 33.5 & 77.5 & 147 & 131 & 145 & 163 & 55.9 & 39.5 & 85.9 & 165.0 & 145 & 151 & 173.0 & 67.5 & 13.5 \\
\hline
\end{tabular}

Note: OM denotes organic matter; CB denotes Cyanobacteria; SOA means sulfate of ammonia, ${ }^{\text {a }}$ Acid ammonium oxalate in darkness, (Loeppert and Inskeep, 1996), ${ }^{\mathrm{b}} 2 \mathrm{M}$ Na-acetate extractble (Loeppert and Inskeep, 1996). 
Table 3. Correlation of $\mathrm{CH}_{4}$ emissions with selected plant parameters and soil properties

\begin{tabular}{lcc}
\hline & & Correlation coefficient $(\mathrm{r})$ \\
\cline { 2 - 3 } \multicolumn{1}{c}{ Parameters $(\mathrm{n}=21)$} & BAU rice field & Bhaluka rice field \\
\hline Panicle number & -0.484 & $-0.493^{*}$ \\
Grain yield & $-0.547^{*}$ & $-0.641^{* *}$ \\
Organic carbon & 0.172 & 0.0445 \\
Soil Porosity & $-0.649^{* *}$ & $-0.729^{* * *}$ \\
Soil pH & $-0.656^{* *}$ & $0.743^{* *}$ \\
Soil Eh & $-0.753^{* * *}$ & $-0.683^{* *}$ \\
Active $\mathrm{Fe}$ & $-0.588^{*}$ & $-0.615^{* *}$ \\
Ferrous $\mathrm{Fe}$ & $-0.695^{* * *}$ & $-0.743^{* * *}$ \\
Water soluble $\mathrm{SO}_{4}{ }^{2-}$ & $-0.738^{* * *}$ & $-.689^{* * *}$ \\
\hline
\end{tabular}

$\mathrm{CH}_{4}$ flux showed a strong positive correlation with the availability of soil organic carbon, while there were negative correlations with soil porosity, soil $\mathrm{pH}$, soil Eh, the content of active iron and ferrous iron oxides, sulphate ion in soil at rice harvesting stage (Table 3). The increased carbon sources in paddy soil enhanced $\mathrm{CH}_{4}$ emissions (Hou et al., 2000; Neue et al., 1996). Rice grain yield was negatively correlated with seasonal $\mathrm{CH}_{4}$ flux (Table 3), which was supported by Denier van der Gon et al. (2002).

\section{Discussion}

In this study $\mathrm{CH}_{4}$ emission patterns were more or less similar in both upland and lowland rice ecosystems, however, $\mathrm{CH}_{4}$ emission rates were significantly higher from the lowland rice field of Bhaluka as compared to upland rice field of BAU. This is likely due to the development of intense anoxic conditions (redox potential value $-240 \mathrm{mV}$ ) and increased availability of labile organic carbon in the lowland rice field ecosystem of Bhaluka, being supported with the findings of Schutz et al.(1989) and Wassmann et al. (1993).

The applied soil amendments significantly decreased the seasonal $\mathrm{CH}_{4}$ emissions during rice cultivation under both ecosystems. Among the amendments silicate slag and phospho-gypsum significantly decreased $\mathrm{CH}_{4}$ emission rate due to their high content of free iron oxides and $\mathrm{SO}_{4}{ }^{-2}$ ions which acted as electron acceptors. The concentration of active iron, $\mathrm{SO}_{4}{ }^{-2}$ and ferrous iron oxides significantly $(\mathrm{p} \varangle 0.001)$ increased in the amended paddy soil (Table 2). Soil porosity increased in the amended paddy soil ecosystems, which might have decreased methane emissions through increasing methane oxidation in the rice rhizosphere.
Ali et al. (2008) found that silicate fertilization in rice farming decreased total $\mathrm{CH}_{4}$ flux by $16-20 \%$, while increased rice productivity by $13-18 \%$ under conventional tillage system. Jugsujinda and Patrick (1996) reported that the ferric iron $\left(\mathrm{Fe}^{3+}\right)$ reduction process delayed or suppressed methane production, although methane production rate was maximum at neutral soil $\mathrm{pH}$ in combination with low soil redox potential (Eh $-250 \mathrm{mV}$ ). In this study, seasonal $\mathrm{CH}_{4}$ emissions showed strong negative correlations with the active iron, $\mathrm{SO}_{4}{ }^{-2}$ and ferrous iron concentrations in soil at harvesting stage (Table 3). This implies that the released iron and sulfate ions from the applied soil amendments acted as electron acceptors and eventually suppressed $\mathrm{CH}_{4}$ emissions as supported by Jackel and Schnell (2000).

\section{Conclusions}

Among the amendments, silicate fertilization with urea and silicate in combination with sulfate of ammonia increased rice grain yield by $18-24 \%$ and 16-18\%, whereas decreased total seasonal $\mathrm{CH}_{4}$ flux by $18-23 \%$ and $21-26 \%$, respectively. Conclusively, silicate fertilization with urea and sulfate of ammonia could be an effective strategy for reducing $\mathrm{CH}_{4}$ emissions during rice cultivation under lowland and upland paddy soil ecosystems.

\section{Acknowledgements}

It is highly acknowledged to the Ministry of Science and Information \& Communication Technology, Govt. of the Peoples Republic of Bangladesh for financial support (MoSICT 2009-2010) to conduct the research experiments. 


\section{References}

Ali, M. A., Chang H. L., Sang Y. K. and Kim, P. J. 2009. Effect of industrial by-products containing electron acceptors on mitigating methane emission during rice cultivation, Waste Management, 29:2759-2764.

Ali, M.A., Lee, C.H., Lee, Y. B. and Kim, P.J., 2009. Silicate fertilization in no-tillage rice farming for mitigation of methane emission and increasing rice productivity. Agril. Ecosyst. Environ. 132: 16-22.

Ali, M.A., Lee, C.H. and Kim, P.J. 2008. Effect of Silicate fertilizer on reducing methane emission during rice cultivation. Biol. Fertil. Soils, 44: 597-604.

Allison, L.E. 1965. Organic carbon, In: Black CA, Evans DD, White JL, Ensminger LE, Clark FE (eds) Methods of soil analysis, part 2.American Society ofAgronomy,Madison,WI, USA, pp. 1367-1376.

Anonymous 1990 SAS/STAT User's guide, vol.1, ACECLUS- FREQ, version 6, 4th edition. SAS Institute, Inc., Cary, NC.

Aulakh, M.S., Bodenbender, J., Wassmann, R. and Rennenberg, H,. 2000. Methane transport capacity of rice plants: Influence of methane concentration and growth stage analyzed with an automated measuring system. Nutr. Cycling Agroecosyst. 58:357-366.

Bharati, K.., Mohanti, S.R., Singh, D.P., Rao, V.P. and Adhya, T.K. 2000. Influence of incorporation or dual cropping of Azolla on methane emission from a flooded alluvial soil planted to rice in eastern India. Agriculture, Ecosystems and Environment, 79: 73-83.

Denier van Der Gon, H.A.C., Kropff, M.J., van Breemen, N., Wassmann, R., Lantin, R.S., Aduna, E., and Corton, T.M. 2002. Optimizing grain yields reduces $\mathrm{CH} 4$ emissions from rice paddy fields. Proc Natl Acad Sci USA 99:1202112024.

Hou, A.X., Chen, G.X., Wang, Z.P., Van Cleemput, O., and Patrick, W.H. Jr. 2000. Methane and nitrous oxide emissions from a rice field in relation to soil redox and microbiological processes. Soil Sci. Soc. Am. J. 64: 2180-2186.

Intergovernmental Panel on Climate Change (IPCC), 2001. The third assessment report. In: Houghton, I.T., Meira, F., Callander, L.G., Harris, B.A., Kattenberg, A., Maskell, K. (Eds.), Climate Change 2001. The Scientific Basis of Climate Cambridge University Press, Cambridge, UK.
Jackel, U. and Schnell S. 2000. Suppression of methane emission from rice paddies by ferric iron fertilization, Soil Biol. Biochemistry, 32(1112): 1811-1814.

Jugsujinda, A., and Patrick Jr., W.H., 1996. Methane and water soluble iron production under controlled soil $\mathrm{pH}$ and redox conditions. Commun. Soil Sci. Plant Anal. 27 (9-10): 22212227.

Loeppert, R.H., and Inskeep, W.P., 1996. Iron. In: Sparks D L, Page A L, Loeppert R H, Johnston C T, Sumner M.E, Bigham J M, (Eds.) Methods of soil analysis, Part 3, Chemical methods, Soil science society of America and American Society of Agronomy, Madison, USA, pp.639664.

Neue, H.U., Wassmann, R., Lantin, R.S., Alberto, M.A.C.R., Aduna, J.B., Javellana, A.M., 1996. Factors affecting methane emission from rice fields. Atmospheric Environment 30 (10):17511754.

Prasanna, R., Kumar, V., Kumar, S., Yadav, A.K.Sethunathan, N. 2002. Methane production in rice soil is inhibited by cyanobacteria, 157: 16.

RDA, Rural Development Administration, 1988. Method of soil chemical analysis. National Institute of Agricultural Science and Technology, Suwon, Korea

Rolston, D.E., 1986. Gas flux, In: Klute A, (ed.) Methods of soil analysis, part $1,2^{\text {nd }}$ ed., Agron. Monogr. 9. ASA and SSSA, Madison, WI. pp. 1103-1119.

Schutz, H., Seiler, W., Conrad, R., 1989. Processes involved in formation and emission of methane in rice paddies, Biogeochem., 7: 33-53.

Watanabe, A. and Kimura, M. 1999. Influence of chemical properties of soils on methane emissions from rice paddies, Commun Soil Sci. Plant Anal, 30,:2449-2463.

Wassmann, R., Papen, H. and Rennenberg, H., 1993. Methane emission from rice paddies and possible mitigation strategies, Chemosphere, 26: 201-217. 